Review

\title{
Huntington's disease: the case for genetic modifiers
}

\author{
James F Gusella and Marcy E MacDonald
}

Address: Molecular Neurogenetics Unit, Center for Human Genetic Research, Massachusetts General Hospital, Boston, MA, 02114, USA.

Correspondence: James F Gusella. E-mail: gusella@helix.mgh.harvard.edu

\begin{abstract}
For almost three decades, Huntington's disease has been a prototype for the application of genetic strategies to human disease. $H D$, the Huntington's disease gene, was the first autosomal defect mapped using only DNA markers, a finding in 1983 that helped to spur similar studies in many other disorders and contributed to the concept of the human genome project. The search for the genetic defect itself pioneered many mapping and gene-finding technologies, and culminated in the identification of the $H D$ gene, its mutation and its novel protein product in 1993. Since that time, extensive investigations into the pathogenic mechanism have utilized the knowledge of the disease gene and its defect but, with notable exceptions, have rarely relied for guidance on the genetic findings in human patients to interpret the relevance of findings in non-human model systems. However, the human patient still has much to teach us through a detailed analysis of genotype and phenotype. Such studies have implicated the existence of genetic modifiers - genes whose natural polymorphic variation contributes to altering the development of Huntington's disease symptoms. The search for these modifiers, much as the search for the HD gene did in the past, offers to open new entrées into the process of Huntington's disease pathogenesis by unlocking the biochemical changes that occur many years before diagnosis, and thereby providing validated target proteins and pathways for development of rational therapeutic interventions.
\end{abstract}

\section{Huntington's disease: a lifelong disease process}

Huntington's disease (HD) is a dominantly inherited disorder in which all affected individuals have precisely the same type of mutation, the expansion of a normally polymorphic CAG trinucleotide repeat in the $H D$ gene, which lengthens a variable polyglutamine tract in the huntingtin protein [1]. Huntingtin is a large HEAT-domain protein expressed in both neuronal and peripheral tissues whose precise function is not known, though dozens of interactions with other proteins have been documented [2]. Despite widespread expression of mutant huntingtin from the time of conception, most individuals with HD are not diagnosed until mid-life, based upon the emergence of adventitious, involuntary movements that progress to a characteristic, all-consuming chorea, due to the gradual loss of neurons, most notably in the striatum and, less distinctly, in the cerebral cortex. The age at which HD can be diagnosed based upon motor symptoms is largely determined by the precise length of the expanded CAG tract, as the two are inversely correlated, with longer CAG repeats leading to earlier onset, sometimes even in the juvenile years (Figure 1) [3]. However, though it is recognized by the movement disorder produced by neuronal dysfunction and degeneration, HD has many other less specific manifestations, including psychiatric disturbances and cognitive decline, as well as non-neuronal phenotypes detected in the periphery. Indeed, the careful examination of $H D$ mutation carriers has revealed a variety of subtle effects (such as cognitive, motor and sensory changes, as well as inflammatory markers) that are detectable many years before clinical diagnosis [4-8]. Characterization of precise genetic mouse models with the equivalent mutation introduced by knock-in techniques into $H d h$, the mouse $H D$ ortholog, indicates that molecular differences are evident even at the embryonic stem (ES) cell stage [9,10]. Thus, inheritance of the $H D$ mutation initiates a lifelong pathogenic process (Figure 2) whose early stages are only beginning to be explored and whose later stages entail clinical diagnosis, progression of neurodegeneration and of disease symptoms, and decline to death, as there is currently no effective treatment for preventing or delaying these. The ultimate goal of HD research is to identify an effective therapy for this devastating disorder (namely, an intervention capable of modifying either the nature or pace of the pathogenic process), recognizing that different modifiers might be required for subjects at the different stages shown in Figure 2.

\section{Genetic modifiers - variation in disease expression determined by genes other than $H D$}

Even though all those with HD have the same type of mutation, two individuals with precisely the same $H D$ CAG length are unlikely to present with movement disorder at exactly the same age (for example, Figure 1), display the identical psychiatric, cognitive or peripheral phenotypes, show equivalent progression of phenotypes, or suffer death 


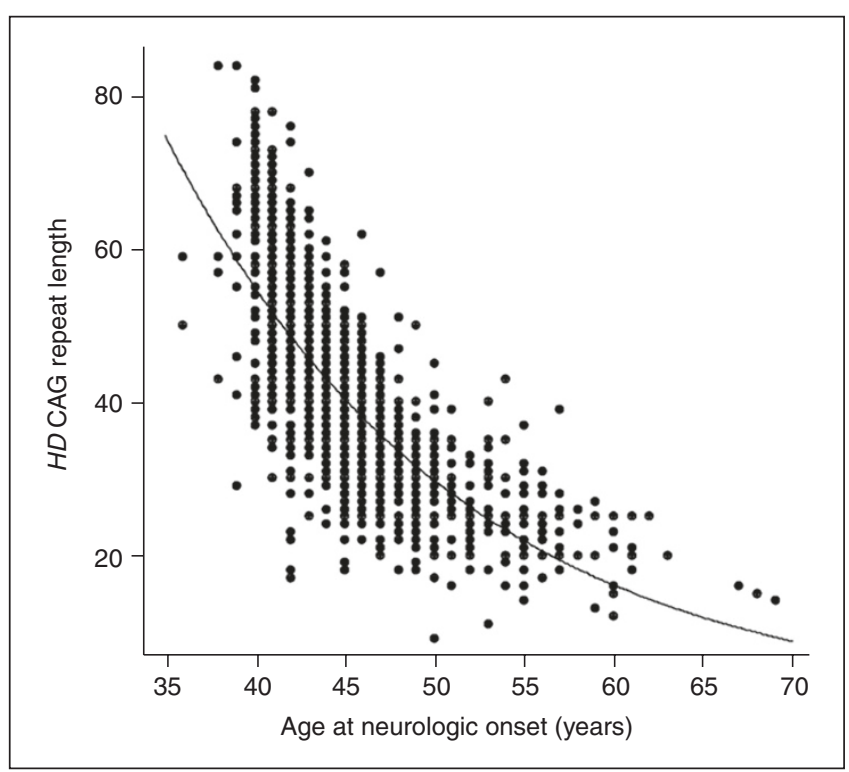

Figure 1

Inverse correlation of age at neurologic onset and HD CAG repeat length. The plot shows data points from 1,200 HD subjects of known age at neurologic onset. For each individual, the measured CAG repeat length in blood DNA ( $x$-axis) is plotted against age at neurologic onset ( $y$-axis). The line represents the best-fit simple logarithmic regression to the data. The CAG repeat length accounts for approximately $67 \%$ of the overall variation in age at neurologic onset, and the remaining variation shows a heritability of approximately 0.56

after an equal disease duration. Although the primary determinants of whether and when a person will exhibit HD are the presence and length, respectively, of the expanded CAG tract, the precise disease manifestations and their timing are clearly modifiable by other factors. These could theoretically be stochastic, environmental/ experiential or genetic, and while all three are likely to be involved to some degree, the latter factors offer the promise of being identified using modern genetic techniques and of then targeting particular biochemical pathways/processes for development of therapeutic interventions. If the genetic modifiers are discovered directly in studies of humans, then the pathways/processes revealed will already be validated to modify the pathogenic process in HD patients, surmounting a major hurdle early in the drug development process.

A gene is a disease modifier if altering its structure or expression alters the manifestation of phenotypes associated with the primary disease mutation, in this case, the $H D$ CAG expansion. In studies in model systems, it is possible to manipulate gene structure or expression through a variety of techniques, but in humans, investigation of genetic modifiers is currently limited to the naturally occurring genetic variation that occurs in human popula-

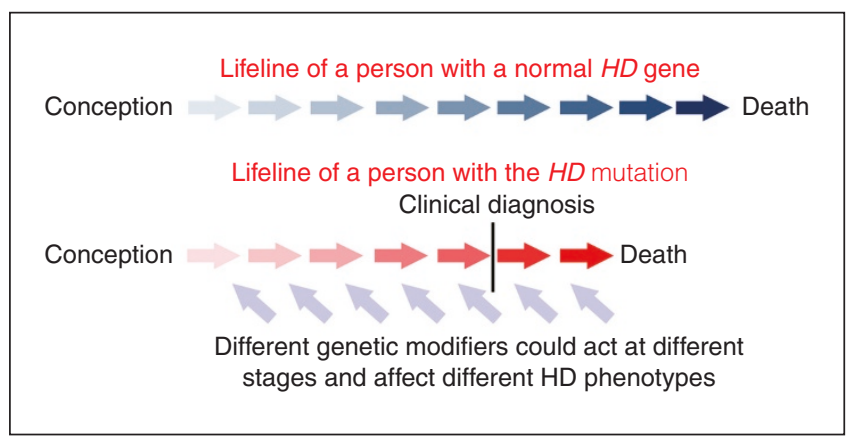

Figure 2

Huntington's disease is a lifelong disorder. The schematic diagram depicts the lifelines of a typical normal individual and a typical individual carrying the $H D$ mutation. The darkening arrows illustrate the changes that occur during the lifetime of each individual as they proceed from conception to death. The use of different colors denotes that the HD subject is never the same as the normal individual, differing even shortly after conception in the expression of mutant huntingtin and its biochemical consequences. The differences lead over time to a variety of phenotypes whose order of appearance and interdependence are not well defined, particularly prior to clinical diagnosis, which is currently based upon the characteristic movement disorder. Death ensues after an inexorable clinical decline, usually approximately 15 years after the appearance of diagnostic movements. Genetic modifiers (blue upward arrows), which could theoretically act at any stage and on any phenotype, are currently being sought for the phenotype of diagnostic motor onset, as the residual variation in this phenotype after accounting for the effect of the HD CAG repeat is highly heritable.

tions. Evidence that heritable factors in humans can alter the course of HD came initially from the HD-MAPS (Modifiers of Age at onset in Pairs of Sibs) study, in which sibling pairs and small families from an international collaborative group were investigated for age at motor onset [11]. It was found that while the length of the $H D$ CAG repeat accounted for $67 \%$ of the variance in age at motor onset, the remaining variance showed a high degree of heritability $(h=0.56)$. This effect was later confirmed in large HD pedigrees from Venezuela, where approximately $40 \%$ of the variation in age at onset remaining after accounting for the effect of CAG repeat length was due to other genetic factors [12]. Other phenotypes have not yet been examined as completely for genetic modifier effects, but it is likely that there will be some degree of impact of human gene variation on each disease feature.

\section{Genetic modifiers - the candidate approach}

The favored strategy to identify genetic modifiers in HD has been a candidate approach in which genes connected to pathways/processes suggested to be involved in HD pathogenesis are examined for genetic variation in humans, and variants are chosen for genotyping in DNAs from manifest HD individuals to test for an effect of genotype on age at motor onset. The results have at best been mixed. 
Perhaps the most clear-cut result with a profound impact on interpretation of HD pathogenesis is the demonstration that a functional polymorphism in the brain-derived neurotrophic factor $(B N D F)$ gene does not modify age at neurologic onset [13-16]. BDNF is a protein thought to be important for the maintenance of striatal neurons, and evidence has emerged in model systems that huntingtin may play a part in regulating BDNF expression [17]. The polymorphism, a Val to Met substitution at position 66, shows evidence of selection in human populations, has been demonstrated to have a significant effect on BDNF secretion, is associated with a number of altered phenotypes in behavioral disorders and brain imaging studies, and acts as a modifier of Parkinson's disease pathogenesis [18-24]. However, the absence of an effect in HD indicates that the demonstrated functional variant in this protein growth factor does not have a significant impact on the events in HD pathogenesis that lead to motor onset. Whether BDNF plays a critical role in the events that occur after motor onset, or in development of other disease features, remains to be tested.

Less clear in their implications for defining early steps in pathogenesis are a number of reported positive results that appear to implicate such processes as glutamatergic transmission (GRIK2, GRIN2A, GRIN2B) [25-31], protein degradation (UCHL1) [31,32], gene transcription (TCERG1, TP53) [33,34], stress response/apoptosis (DFFB, MAP3K5, MAP2K6) [34,35], lipoprotein metabolism (APOE) [36], axonal trafficking (HAP1) [37], folate metabolism (MTHFR) [38], and energy metabolism (PPARGC1A) [39,40] as having small effects on age at motor onset. In some cases, gender stratification implied a sex-specific effect ( $A P O E$, GRIN2A, GRIN2B, MAP2K6) [30,35,36]. Complicating the assessment of many of the modifier investigations is the small sample size in many studies, the failure to correct for multiple hypothesis testing when several polymorphisms, genes or models were examined, and the potential confounding effects of sample relatedness and population stratification. In many cases, initial positive reports have been followed by negative studies of the same polymorphisms (for example, GRIN2B, UCHL1, TP53, DFFB, APOE, MTHFR) [41-44] or have not yet been confirmed (HAP1, MAP $\left.3 K_{5}, M A P 2 K 6\right)$. In others, a follow-up study has trended in the same direction or yielded marginally significant findings (TCERG1, GRIN2A) [41]. In the case of PPARGC1A, two independent positive reports appeared simultaneously, showing association of age at onset with an intronic polymorphism whose functional significance has not been determined [39,40]. GRIK2, the earliest reported genetic modifier, has shown an effect in multiple studies where a particular allele of a $3^{\prime}$ UTR (untranslated region) TAA trinucleotide repeat appears to be associated with earlier onset of HD [26-28,31]. Sequencing of the GRIK2 gene, and haplotype studies in individuals showing earlier than expected onset, suggest that the effect is due to the TAA repeat allele itself, rather than to some nearby coding or regulatory polymorphism in the GRIK2 gene.

None of these modifier studies has yet revealed a specific mechanism by which the genetic variation has its apparent effects, which will be required to use these findings as a guide to rational therapeutic development. In addition to these candidate processes, age-related instability of the $H D$ CAG repeat, which is particularly evident in the brain, may increase the severity of the disease process and is correlated with an earlier than expected age at onset of motor symptoms, suggesting that factors involved in generating the repeat length differences merit exploration as potential modifiers of the insult that initiates the disease process $[45,46]$.

\section{Genetic modifiers - the unbiased approach}

The alternative approach of performing unbiased searches for genetic modifiers to reveal potential unsuspected factors has begun to be employed in HD. In lower organisms, these have taken the form of genetic screens to identify genes that modify some specific phenotype in an engineered animal model. For example, screens in yeast, Caenorhabditis elegans and Drosophila melanogaster expressing an introduced fragment from human huntingtin consisting largely of polyglutamine have yielded a number of modifiers of the effects of this fragment [47-50]. Indeed, in the Drosophila system, the orthologs of proteins that interact physically with human huntingtin have been suggested to be over-represented among modifiers. While the non-human systems are certainly more manipulable and yield modifiers more readily, they have two major drawbacks.

The first is that in none of these systems is the mechanism that leads to the phenotype being screened necessarily the same mechanism that triggers the disease in humans. As the effects in humans begin with the expression of a fulllength mutant huntingtin protein, much or all of the pathogenic pathway may not be reproduced in animals that express only a small fragment of foreign protein. The models that most closely match the genetic basis of HD are mouse models that express full-length mutant protein, particularly those generated by knock-in technology that uses $H d h$, the endogenous mouse $H D$ ortholog. Both yeast artificial chromosome (YAC) transgenic and knock-in HD mice display a variety of phenotypes that are modifiable by genetic background, but no systematic screen for modifiers has yet been performed [51,52].

The second major drawback of non-human model systems is inherent even in the genetically equivalent mouse models: modifiers identified in these systems must still be validated in humans, as they may reflect biology peculiar to the model organism used. The need for validation re-introduces a costly, time-consuming and inherently uncertain step in using the result for development of 
therapeutics, a step that is obviated by identifying the genetic modifiers directly in humans. The attempt to validate findings in animal studies can be problematic and may never be definitive until an intervention based upon the result is tested in humans.

The initial unbiased scans for human modifiers have relied on genetic linkage to search for chromosome regions associated with alteration of age at neurologic onset from that expected based upon the CAG repeat length in the individuals tested. HD-MAPS, a large collaborative study involving HD groups from around the world, performed this analysis in sibling pairs and small families by genomewide microsatellite genotyping, and identified a number of possible regions of genetic linkage [53]. A follow-up study with additional samples achieved a genome-wide significant score for a region of $6 \mathrm{q}$, indicating the frequent presence of genetic variation in this region that modifies HD pathogenesis prior to neurologic onset [54]. Subsequently, a similar scan in sibships of the Venezuela pedigrees studied by the US-Venezuela Collaborative Group identified genome-wide significant genetic linkage to $2 \mathrm{p}$, and several other possible regions of linkage, including 6q [55]. In both cases, the genomic regions implicated are quite large and have not yet yielded specific modifier genes responsible for the effect.

Advances in the understanding of overall human genetic variation and the technologies for rapidly assessing it in large numbers of individuals have led to the possibility of performing genome-wide studies using densely spaced single-nucleotide polymorphisms (SNPs) and copy number probes. These are now being applied in an expanded version of the HD-MAPS collaboration, to search for association with age at neurologic onset. These investigations, which will have a much larger sample size of several thousand HD subjects, should clarify the candidate human modifier genes described above, narrow the known linkage peaks, and identify new polymorphisms that exhibit association with age at neurologic onset.

\section{Future directions}

It is likely that capitalizing on the rapid advances in the capacity for genome-wide genetic research in humans will prove the most rapid and definitive way to identify validated genetic modifiers of $\mathrm{HD}$ pathogenesis. This approach has the added advantage that once the genomewide genotyping has been performed, it will be possible to mine the same dataset to identify genetic modifiers of other phenotypes defined in the participating HD subjects. For example, modifiers of the disease progression that takes place after many of the vulnerable striatal neurons have already died may well reveal different pathways and targets for intervention. Similarly, genetic modifiers of behavioral symptoms may reveal targets for intervention that are applicable years before motor onset, but which represent different branches of pathogenesis. Once a genetic variation has been found to affect a particular human HD phenotype, it can be incorporated into the design of clinical trials involving that phenotype. The interventions that these trials are designed to test are putative modifiers, chemical or otherwise, of HD pathogenesis, and the inclusion of genotype for important genetic variations that also modify HD pathogenesis will increase the power of the clinical trials to detect an effect of the intervention by controlling for the effect of the genetic background of each test subject.

Ultimately, for any genetic modifier to itself be useful in leading to an intervention, it will be necessary to define at least in part the mechanism of action of the genetic variation that has the modifier effect, in order to know how to use the implicated pathways or proteins as targets for therapeutic development. This will require the use of model systems, though the human must remain the gold standard, due to the critical importance of knowing that the mechanism being defined in the model actually occurs in human patients. A major hope in this regard is the development of induced pluripotent stem (iPS) cell technology, which offers the promise of providing pluripotent cells and differentiated products from individual human subjects. These will represent a tremendous resource both for defining the effect of validated genetic modifiers on $H D$ mutation-dependent cellular phenotypes, as a route to discovering the mechanisms involved in genetic modification, and also for carrying out human cellbased genetic screens (for example, RNA interference, overexpression) to identify modifiers that were not found in the genome-wide genetic studies, perhaps due to a lack of inherent functional variation in the human population.

\section{Conclusions}

HD is a lifelong disorder whose genetic trigger was found by application of genetic strategies to DNA from human patients. The continued application of these strategies is a powerful way to identify genetic factors that are capable of altering disease pathogenesis. The same argument can be made for any late-onset disorder where the presence of an ongoing disease process can be predicted prior to diagnosis based upon genotype. Indeed, the approach is no longer limited by genetic technologies, but only by the need for detailed quantitative and qualitative phenotyping in large cohorts of individuals at all stages of the disease process, both pre-diagnosis and post-diagnosis. As the same detailed phenotyping of patient cohorts for defining natural history and biomarkers is required to design and carry out effective clinical trials, the increased emphasis in the HD community on examination of early phenotypic changes in human patients should support both the identification of validated targets and the testing of interventions aimed at these targets, in genetically stratified clinical trials. 


\section{Competing interests}

The authors declare that they have no competing interests.

\section{Authors' contributions}

JFG and MEM both drafted the manuscript and approved its final version.

\section{Acknowledgements}

The authors' work on Huntington's disease is supported by $\mathrm{NIH}$ NINDS grants NS32765 and NS16367, the Huntington's Disease Society of America Coalition for the Cure, an anonymous donor and the CHDI Foundation, Inc.

\section{References}

1. Huntington's Disease Collaborative Research Group: A novel gene containing a trinucleotide repeat that is expanded and unstable on Huntington's disease chromosomes. Cell 1993, 72:971-983.

2. Gusella JF, MacDonald ME: Huntingtin: a single bait hooks many species. Curr Opin Neurobiol 1998, 8:425-430.

3. Gusella JF, Macdonald ME: Huntington's disease: seeing the pathogenic process through a genetic lens. Trends Biochem Sci 2006, 31:533-540.

4. Paulsen JS, Langbehn DR, Stout JC, Aylward E, Ross CA, Nance M, Guttman M, Johnson S, MacDonald M, Beglinger LJ, Duff K, Kayson E, Biglan K, Shoulson I, Oakes D, Hayden M: Detection of Huntington's disease decades before diagnosis: the Predict-HD study. J Neurol Neurosurg Psychiatry 2008, 79:874-880.

5. Bjorkqvist M, Wild EJ, Thiele J, Silvestroni A, Andre R, Lahiri N, Raibon E, Lee RV, Benn CL, Soulet D, Magnusson A Woodman B, Landles C, Pouladi MA, Hayden MR, KhaliliShirazi A, Lowdell MW, Brundin P, Bates GP, Leavitt BR, Möller T, Tabrizi S: A novel pathogenic pathway of immune activation detectable before clinical onset in Huntington's disease. J Exp Med 2008, 205:1869-1877.

6. Dalrymple A, Wild EJ, Joubert R, Sathasivam K, Bjorkqvist M, Petersen A, Jackson GS, Isaacs JD, Kristiansen M, Bates GP Leavitt BR, Keir G, Ward M, Tabrizi S: Proteomic profiling of plasma in Huntington's disease reveals neuroinflammatory activation and biomarker candidates. J Proteome Res 2007, 6:2833-2840.

7. Kirkwood SC, Siemers E, Hodes ME, Conneally PM, Christian $\mathrm{JC}$, Foroud T: Subtle changes among presymptomatic carriers of the Huntington's disease gene. J Neurol Neurosurg Psychiatry 2000, 69:773-779.

8. Rosas HD, Hevelone ND, Zaleta AK, Greve DN, Salat DH, Fischl B: Regional cortical thinning in preclinical Huntington disease and its relationship to cognition. Neurology 2005, 65:745-747.

9. Shelbourne PF, Killeen N, Hevner RF, Johnston HM, Tecott L, Lewandoski M, Ennis M, Ramirez L, Li Z, lannicola C, Littman DR, Myers R: A Huntington's disease CAG expansion at the murine $\mathrm{Hdh}$ locus is unstable and associated with behavioural abnormalities in mice. Hum Mol Genet 1999, 8:763774

10. White JK, Auerbach W, Duyao MP, Vonsattel JP, Gusella JF, Joyner AL, MacDonald ME: Huntingtin is required for neurogenesis and is not impaired by the Huntington's disease CAG expansion. Nat Genet 1997, 17:404-410.

11. Djousse L, Knowlton B, Hayden M, Almqvist EW, Brinkman R, Ross C, Margolis R, Rosenblatt A, Durr A, Dode C, Morrison PJ, Novelletto A, Frontali M, Trent RJ, McCusker E, GómezTortosa E, Mayo D, Jones R, Zanko A, Nance M, Abramson R, Suchowersky O, Paulsen J, Harrison M, Yang Q, Cupples LA, Gusella JF, MacDonald ME, Myers RH: Interaction of normal and expanded CAG repeat sizes influences age at onset of Huntington disease. Am J Med Genet 2003, 119A(3):279282.

12. Wexler NS, Lorimer J, Porter J, Gomez F, Moskowitz C, Shackell E, Marder K, Penchaszadeh G, Roberts SA, Gayan J,
Brocklebank D, Cherny SS, Cardon LR, Gray J, Dlouhy SR, Wiktorski S, Hodes ME, Conneally PM, Penney JB, Gusella J, Cha JH, Irizarry M, Rosas D, Hersch S, Hollingsworth Z, MacDonald M, Young AB, Andresen JM, Housman DE, De Young MM, et al: Venezuelan kindreds reveal that genetic and environmental factors modulate Huntington's disease age of onset. Proc Natl Acad Sci USA 2004, 101:3498-3503.

13. Di Maria E, Marasco A, Tartari M, Ciotti P, Abbruzzese G Novelli G, Bellone E, Cattaneo E, Mandich P: No evidence of association between $B D N F$ gene variants and age-at-onset of Huntington's disease. Neurobiol Dis 2006, 24:274-279.

14. Kishikawa S, Li JL, Gillis T, Hakky MM, Warby S, Hayden M, MacDonald ME, Myers RH, Gusella JF: Brain-derived neurotrophic factor does not influence age at neurologic onset of Huntington's disease. Neurobiol Dis 2006, 24:280-285.

15. Mai M, Akkad AD, Wieczorek S, Saft C, Andrich J, Kraus PH, Epplen JT, Arning L: No association between polymorphisms in the BDNF gene and age at onset in Huntington disease. BMC Med Genet 2006, 7:79.

16. Metzger S, Bauer P, Tomiuk J, Laccone F, Didonato S, Gellera C, Mariotti C, Lange HW, Weirich-Schwaiger H, Wenning GK, Seppi K, Melegh B, Havasi V, Balikó L, Wieczorek S, Zaremba J, Hoffman-Zacharska D, Sulek A, Basak AN, Soydan E, Zidovska J, Kebrdlova V, Pandolfo M, Ribaï P, Kadasi L, Kvasnicova M Weber BH, Kreuz F, Dose M, Stuhrmann M, et al: Genetic analysis of candidate genes modifying the age-at-onset in Huntington's disease. Hum Genet 2006, 120:285-292.

17. Zuccato $\mathrm{C}$, Cattaneo $\mathrm{E}$ : Brain-derived neurotrophic factor in neurodegenerative diseases. Nat Rev Neurol 2009, 5:311322.

18. Gasic GP, Smoller JW, Perlis RH, Sun M, Lee S, Kim BW, Lee MJ, Holt DJ, Blood AJ, Makris N, Kennedy DK, Hoge RD, Calhoun J, Fava M, Gusella JF, Breiter HC: BDNF, relative preference, and reward circuitry responses to emotional communication. Am J Med Genet B Neuropsychiatr Genet 2009, 22 April [Epub ahead of print].

19. Petryshen TL, Sabeti PC, Aldinger KA, Fry B, Fan JB, Schaffner SF, Waggoner SG, Tahl AR, Sklar P: Population genetic study of the brain-derived neurotrophic factor (BDNF) gene. Mol Psychiatry 2009, 3 March [Epub ahead of print]

20. Savitz JB, Drevets WC: Imaging phenotypes of major depressive disorder: genetic correlates. Neuroscience 2009, 7 April [Epub ahead of print].

21. Cheeran BJ, Ritter C, Rothwell JC, Siebner HR: Mapping genetic influences on the corticospinal motor system in humans. Neuroscience 2009, 2 February [Epub ahead of print]

22. Rybakowski JK: BDNF gene: functional Val66Met polymorphism in mood disorders and schizophrenia Pharmacogenomics 2008, 9:1589-1593.

23. Karamohamed S, Latourelle JC, Racette BA, Perlmutter JS Wooten GF, Lew M, Klein C, Shill H, Golbe LI, Mark MH, Guttman M, Nicholson G, Wilk JB, Saint-Hilaire M, DeStefano AL, Prakash R, Tobin S, Williamson J, Suchowersky O, Label N, Growdon BN, Singer C, Watts R, Goldwurm S, Pezzoli G, Baker KB, Giroux ML, Pramstaller PP, Burn DJ, Chinnery P, et al: $B D N F$ genetic variants are associated with onset age of familial Parkinson disease: GenePD Study. Neurology 2005, 65:1823-1825

24. Egan MF, Kojima M, Callicott JH, Goldberg TE, Kolachana BS, Bertolino A, Zaitsev E, Gold B, Goldman D, Dean M, Lu B, Weinberger DR: The BDNF val66met polymorphism affects activity-dependent secretion of BDNF and human memory and hippocampal function. Cell 2003, 112:257-269.

25. Cannella M, Gellera C, Maglione V, Giallonardo P, Cislaghi G, Muglia M, Quattrone A, Pierelli F, Di Donato S, Squitieri F: The gender effect in juvenile Huntington disease patients of Italian origin. Am J Med Genet B Neuropsychiatr Genet 2004, 125B:92-98.

26. Chattopadhyay B, Ghosh S, Gangopadhyay PK, Das SK, Roy T, Sinha KK, Jha DK, Mukherjee SC, Chakraborty A, Singha BS, Bhattacharya AK, Bhattacharyya NP: Modulation of age at onset in Huntington's disease and spinocerebellar 
ataxia type 2 patients originated from eastern India. Neurosci Lett 2003, 345:93-96.

27. MacDonald ME, Vonsattel JP, Shrinidhi J, Couropmitree NN, Cupples LA, Bird ED, Gusella JF, Myers RH: Evidence for the GluR6 gene associated with younger onset age of Huntington's disease. Neurology 1999, 53:1330-1332.

28. Rubinsztein DC, Leggo J, Chiano M, Dodge A, Norbury G, Rosser E, Craufurd D: Genotypes at the GluR6 kainate receptor locus are associated with variation in the age of onset of Huntington disease. Proc Natl Acad Sci USA 1997, 94:3872-3876.

29. Arning L, Kraus PH, Valentin S, Saft C, Andrich J, Epplen JT: NR2A and NR2B receptor gene variations modify age at onset in Huntington disease. Neurogenetics 2005, 6:25-28.

30. Arning L, Saft C, Wieczorek S, Andrich J, Kraus PH, Epplen JT: NR2A and NR2B receptor gene variations modify age at onset in Huntington disease in a sex-specific manner. Hum Genet 2007, 122:175-182.

31. Naze P, Vuillaume I, Destee A, Pasquier F, Sablonniere B: Mutation analysis and association studies of the ubiquitin carboxy-terminal hydrolase L1 gene in Huntington's disease. Neurosci Lett 2002, 328:1-4.

32. Metzger S, Bauer P, Tomiuk J, Laccone F, Didonato S, Gellera $C$, Soliveri $P$, Lange HW, Weirich-Schwaiger H, Wenning GK, Melegh B, Havasi V, Balikó L, Wieczorek S, Arning L, Zaremba J, Sulek A, Hoffman-Zacharska D, Basak AN, Ersoy N, Zidovska J, Kebrdlova V, Pandolfo M, Ribaï P, Kadasi L, Kvasnicova M, Weber BH, Kreuz F, Dose M, Stuhrmann M, et al: The S18Y polymorphism in the UCHL1 gene is a genetic modifier in Huntington's disease. Neurogenetics 2006, 7:27-30.

33. Holbert S, Denghien I, Kiechle T, Rosenblatt A, Wellington C, Hayden MR, Margolis RL, Ross CA, Dausset J, Ferrante RJ, Néri C: The GIn-Ala repeat transcriptional activator CA150 interacts with huntingtin: neuropathologic and genetic evidence for a role in Huntington's disease pathogenesis. Proc Natl Acad Sci USA 2001, 98:1811-1816.

34. Chattopadhyay B, Baksi K, Mukhopadhyay S, Bhattacharyya NP: Modulation of age at onset of Huntington disease patients by variations in TP53 and human caspase activated DNase (hCAD) genes. Neurosci Lett 2005, 374:81-86.

35. Arning L, Monte D, Hansen W, Wieczorek S, Jagiello P, Akkad DA, Andrich J, Kraus PH, Saft C, Epplen JT: ASK1 and MAP2K6 as modifiers of age at onset in Huntington's disease. J Mol Med 2008, 86:485-490.

36. Kehoe P, Krawczak M, Harper PS, Owen MJ, Jones AL: Age of onset in Huntington disease: sex specific influence of apolipoprotein E genotype and normal CAG repeat length. J Med Genet 1999, 36:108-111.

37. Metzger S, Rong J, Nguyen HP, Cape A, Tomiuk J, Soehn AS, Propping P, Freudenberg-Hua Y, Freudenberg J, Tong L, Li SH, Li XJ, Riess O: Huntingtin-associated protein-1 is a modifier of the age-at-onset of Huntington's disease. Hum Mol Genet 2008, 17:1137-1146.

38. Brune N, Andrich J, Gencik M, Saft C, Muller T, Valentin S, Przuntek H, Epplen JT: Methyltetrahydrofolate reductase polymorphism influences onset of Huntington's disease. $J$ Neural Transm Suppl 2004, 68:105-110.

39. Taherzadeh-Fard E, Saft C, Andrich J, Wieczorek S, Arning L: PGC-1alpha as modifier of onset age in Huntington disease. Mol Neurodegener 2009, 4:10.

40. Weydt P, Soyal SM, Gellera C, Didonato S, Weidinger C, Oberkofler H, Landwehrmeyer GB, Patsch W: The gene coding for PGC-1alpha modifies age at onset in Huntington's Disease. Mol Neurodegener 2009, 4:3.

41. Andresen JM, Gayan J, Cherny SS, Brocklebank D, AlkortaAranburu G, Addis EA, Cardon LR, Housman DE, Wexler NS: Replication of twelve association studies for Huntington's disease residual age of onset in large Venezuelan kindreds. J Med Genet 2007, 44:44-50.

42. Hansen W, Saft C, Andrich J, Muller T, Wieczorek S, Epplen JT, Arning L: Failure to confirm influence of methyltetrahydrofolate reductase (MTHFR) polymorphisms on age at onset of Huntington disease. J Negat Results Biomed 2005, 4:12.
43. Arning L, Kraus PH, Saft C, Andrich J, Epplen JT: Age at onset of Huntington disease is not modulated by the R72P variation in TP53 and the R196K variation in the gene coding for the human caspase activated DNase (hCAD). BMC Med Genet 2005, 6:35.

44. Saft C, Andrich JE, Brune N, Gencik M, Kraus PH, Przuntek H, Epplen JT: Apolipoprotein E genotypes do not influence the age of onset in Huntington's disease. J Neurol Neurosurg Psychiatry 2004, 75:1692-1696.

45. Swami M, Hendricks AE, Gillis T, Massood T, Mysore J, Myers $\mathrm{RH}$, Wheeler VC: Somatic expansion of the Huntington's disease CAG repeat in the brain is associated with an earlier age of disease onset. Hum Mol Genet 2009, 18:30393047.

46. Veitch NJ, Ennis M, McAbney JP, Shelbourne PF, Monckton DG: Inherited CAG.CTG allele length is a major modifier of somatic mutation length variability in Huntington disease. DNA Repair 2007, 6:789-796.

47. Kaltenbach LS, Romero E, Becklin RR, Chettier R, Bell $R$ Phansalkar A, Strand A, Torcassi C, Savage J, Hurlburt A, Cha GH, Ukani L, Chepanoske CL, Zhen Y, Sahasrabudhe S, Olson J, Kurschner C, Ellerby LM, Peltier JM, Botas J, Hughes RE: Huntingtin interacting proteins are genetic modifiers of neurodegeneration. PLoS Genet 2007, 3:e82.

48. Giorgini F, Guidetti P, Nguyen Q, Bennett SC, Muchowski PJ: A genomic screen in yeast implicates kynurenine 3-monooxygenase as a therapeutic target for Huntington disease. Nat Genet 2005, 37:526-531.

49. Jia K, Hart AC, Levine B: Autophagy genes protect against disease caused by polyglutamine expansion proteins in Caenorhabditis elegans. Autophagy 2007, 3:21-25.

50. Parker JA, Holbert S, Lambert E, Abderrahmane S, Neri C: Genetic and pharmacological suppression of polyglutamine-dependent neuronal dysfunction in Caenorhabditis elegans. J Mol Neurosci 2004, 23:61-68

51. Lloret A, Dragileva E, Teed A, Espinola J, Fossale E, Gillis T, Lopez E, Myers RH, MacDonald ME, Wheeler VC: Genetic background modifies nuclear mutant huntingtin accumulation and HD CAG repeat instability in Huntington's disease knock-in mice. Hum Mol Genet 2006, 15:2015-2024.

52. Van Raamsdonk JM, Metzler M, Slow E, Pearson J, Schwab C, Carroll J, Graham RK, Leavitt BR, Hayden MR: Phenotypic abnormalities in the YAC128 mouse model of Huntington disease are penetrant on multiple genetic backgrounds and modulated by strain. Neurobiol Dis 2007, 26:189-200.

53. Li JL, Hayden MR, Almqvist EW, Brinkman RR, Durr A, Dode C, Morrison PJ, Suchowersky O, Ross CA, Margolis RL, Rosenblatt A, Gómez-Tortosa E, Cabrero DM, Novelletto A, Frontali M, Nance M, Trent RJ, McCusker E, Jones R, Paulsen JS, Harrison M, Zanko A, Abramson RK, Russ AL, Knowlton B, Djoussé L, Mysore JS, Tariot S, Gusella MF, Wheeler VC, et al: A genome scan for modifiers of age at onset in Huntington disease: The HD MAPS study. Am J Hum Genet 2003, 73: 682-687.

54. Li JL, Hayden MR, Warby SC, Durr A, Morrison PJ, Nance M, Ross CA, Margolis RL, Rosenblatt A, Squitieri F, Frati L, Gómez-Tortosa E, García CA, Suchowersky O, Klimek ML, Trent RJ, McCusker E, Novelletto A, Frontali M, Paulsen JS, Jones R, Ashizawa T, Lazzarini A, Wheeler VC, Prakash R, Xu G, Djoussé L, Mysore JS, Gillis T, Hakky M, et al: Genomewide significance for a modifier of age at neurological onset in Huntington's disease at 6q23-24: the HD MAPS study. BMC Med Genet 2006, 7:71.

55. Gayan J, Brocklebank D, Andresen JM, Alkorta-Aranburu G, Zameel Cader M, Roberts SA, Cherny SS, Wexler NS, Cardon LR, Housman DE: Genomewide linkage scan reveals novel loci modifying age of onset of Huntington's disease in the Venezuelan HD kindreds. Genet Epidemiol 2008, 32:445-453.

Published: 21 August 2009

doi:10.1186/gm80

(c) 2009 BioMed Central Ltd 